DOI 10.7251/SCMED1802118T

ORIGINAL SCIENTIFIC ARTICLE
UDC 159.942.5.072:616.711-007.5-06

COBISS.RS-ID 7837976

\title{
Effects of Anxiety and Depressive Manifestations of Personality on Functional Recovery of Patients with Cervical Pain Syndrome
}

\begin{abstract}
Introduction: Cervical syndrome is a set of symptoms that are manifested by pain in the neck segment and shoulder blade region, with the feeling of tightness and tension, and limited movement of the neck segment of the spine. Because of the long-term duration of symptoms, we often find psychopathological manifestations in the form of anxiety and depression in these patients.
\end{abstract}

Objective: The goal was to detect the presence of anxiety and depressive manifestations of personality in patients with cervical syndrome at the beginning of rehabilitation treatment, to determine to what extent the presence of anxiety and depressive symptomatology affects the functional recovery of patients after a physical rehabilitation treatment.

Patients and Methods: The study was conducted as a prospective study involving 100 patients. Criteria for inclusion were the diagnosis of cervical syndrome and the age of patients between 20 and 60 years of age. Exclusion criteria were diagnosis of cervical radiculopathy, vertebrobasilar syndrome, diagnosis of anxiety and depressionconfirmed by psychiatrist, as well as use of psychotropic substances. On admission, each patient filled in Beck's questionaire for anxiety and depression (BAl and BDI)and accordingly patients were divided into 3 groups.

Results: Out of total of 100 patients, $74 \%$ were female and $26 \%$ were male. In $77 \%$ of patients psychopathological manifestations of personality were found. A statistically significant association of gender and group placement was found $(p=0,003)$. The women had a far greater percentage of anxiety and anxietydepressive manifestations of the personality than men. In terms of BAI and BDI, there was a statistically significant difference between genders. All of the parameters ( VAS, Schober, CSS) monitored during rehabilitation treatment were improved at the end of treatment $(p=0,0001)$. There was a positive correlation of BAI and BDI with CSS on admission and at discharge $(p=0,05)$ in a group of anxiety-depressed patients.

Conclusion: The presence of anxiety and depressive manifestations of personality did not have a negative impact on the functional recovery of patients. Physical therapy has led to reduction of pain, increased mobility and better functional status of cervical spine for patients with cervical spine syndrome.

Key words: cervical syndrome, functional recovery, depression, anxiety

(Scr Med 2018:49:118-125)

Sandra Trivunović, Tatjana Nožica

Radulovići, ${ }^{1,2}$ Goran Talić, ${ }^{1,2}$, Boris Prodanović ${ }^{1}$ Jelena Stanković, Jelena Nikolić Pucar ${ }^{1}$

${ }^{1}$ Institute for Physical Medicine and Rehabilitation "Dr Miroslav Zotović, Banja Luka

${ }^{2}$ Faculty of Medicine, University of Banja Luka, Banja Luka, Republic of Srpska, Bosnia and Herzegovina

Corresponding author: Sandra Trivunović e-mail: sandra.tepic@yahoo.com
Manuscript received: November $9^{\text {th }}, 2018$ Manuscript accepted: November $25^{\text {th }}, 2018$ 


\section{Introduction}

Cervical syndrome is a set of symptoms that are manifested by pain in the neck segment and shoulder blade region, with the feeling of tightness and tension, and limited movement of the neck segment of the spine. In some cases, pain can spread towards the back of the head, in which case we are talking about cervicocranial syndrome (Syndroma cervicocraniale), or towards the shoulder and arm when we talk about cervibrachiale syndrome (Syndroma cervicobrachiale). ${ }^{1,2}$. The causes of the onset of this painful state are numerous, but the most common cause is the degenerative diseases of the vertebra and intervertebral discs. ${ }^{1,2,3}$ In addition, cervical syndrome can also occure due to injuries in the cervical spine region, inflammatory rheumatism, infections as well as in malignant diseases.

Risks for developing this disorder are related with working in poor microclimatic conditions and in the non-physiological position of the body. The majority of patients fall into the working age population, aged between 40 and 55 years. $4,5,6$

Resulting changes in affected cervical spine and surrounding soft tissues cause pain wich in turn results in reduction of mobility, weaknes and increased muscle tension , and consequently a poorer quality of life.7 In order to alleviate the symptoms of these patients, several types of therapies are applied which can reduce the symptoms, reduce pain and improve the function of the cervical spine. Physical therapy is, in addition to medication and education of patients, the basis of conservative treatment for this painful condition..$^{8,9}$

Because of the long-term duration of symptoms, we often find psychopathological manifestations in the form of anxiety and depression in these patients..$^{10,11,13}$ These symptoms should be noted on the first encounter with patient because they can slow down functional recovery. Team approach to this issue can provide comprehensive treatment aimed to relieve symptoms as well as a timely professional and social reintegration.

The goal of his research was to detect the presence of anxiety and depressive manifestations of personality in patients with cervical syndrome at the beginning of rehabilitation treatment, to determine to what extent the presence of anxiety and depressive symptomatology affects the functional recovery of patients after a physical rehabilitation treatment.

\section{Objective}

The goal was to detect the presence of anxiety and depressive manifestations of personality in patients with cervical syndrome at the beginning of rehabilitation treatment, to determine to what extent the presence of anxiety and depressive symptomatology affects the functional recovery of patients after a physical rehabilitation treatment.

\section{Patients and Methods}

Research was conducted as a prospective study wich included 100 patients of both gender. Criteria for inclusion were the diagnosis of cervical syndrome (pain in the neck and shoulder blade region lasting longer than 6 months, feelling of tension, limited mobility of cervical spine) and the age of patients between 20 and 60 years of age. Exclusion criteria were diagnosis of cervical radiculopathy, vertebrobasilar syndrome, diagnosis of anxiety and/or depression confirmed by psychiatrist, as well as use of psychotropic substances. On admission, each patient filled in Beck's questionaire for anxiety and depression (BAI and BDI) and accordingly patients were divided into 3 groups. First group - no manifestations, included 32 patients, second group- anxiety personality manifestations included 41 patients, and third groupanxiety-depressive personality manifestations included 21 patients. Each patient was assessed on admission and at discharge using Cervical Spine Score (CSS) for cervical spine function, Visual Analogue Scale (VAS) for pain intensity and Schober's index of sagittal mobility for cervical spine. All patients were treated as stationary patients at Depratment V of Rehabilitation centre „dr Miroslav Zotović", Banja Luka, in average of 19 days (mean 19,07 st.dev 1,8 days). Their treatment included therapeutic exercise treatment and application of other physical therapy modalities. Patients who had anxiety and depressive manifestations of personality were included in relaxation groups under the supervision of a psychologist. This research was approved by the Ethics Committee. Each patient signed the Informed consent to participate. The obtained data were statisticaly analyzed using the following statistical tests, parametric(independent Student T test, ANOVA, Tukey test) and non-parametric( Mann Witnney, Kruskal Wallis test).

\section{Results}

In this study, out of a total of 100 patients, $74 \%$ were women and $26 \%$ were men. There were no significant differences in age between men and women (Table 1). 
Table 1. Patient distribution by age

\begin{tabular}{lccc} 
Gender & N & Mean (age) & St. dev. \\
M & 24 & 53.31 & 7.55 \\
F & 76 & 55.50 & 7.72 \\
Total & 100 & 54.93 & 7.30 \\
\hline
\end{tabular}

In $77 \%$ of the patients, psychopathological manifestations of the personality (anxiety and anxiety-depressive) were found. The statistically significant association of gender and belonging to the group ( $\mathrm{x} 2=11.5 ; \mathrm{p}=0.003$, Figure 1) was found. The women were in a far greater percentage for anxiety and anxiety -depressive disorder.

Figure 1. Gender representation in groups of patients without and with anxiety and anxiety / depressive manifestations of the personality.

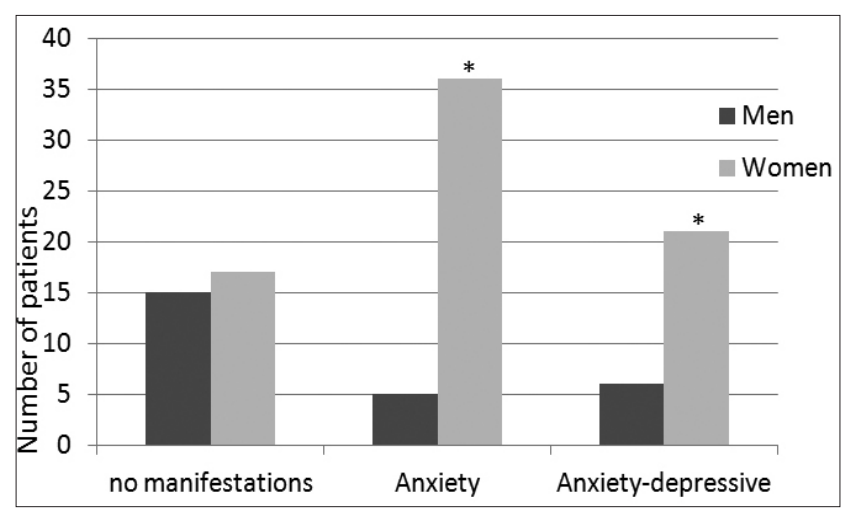

* $p=0.003$ versus men within the same manifestation of personality.

There was a statistically significant difference between men and women regarding the BDI and BAI (women have higher scores, Figure 2).

Figure 2. Values of Beck's Depression Index (BDI) and Beck's Anxiety Index (BAI) versus gender

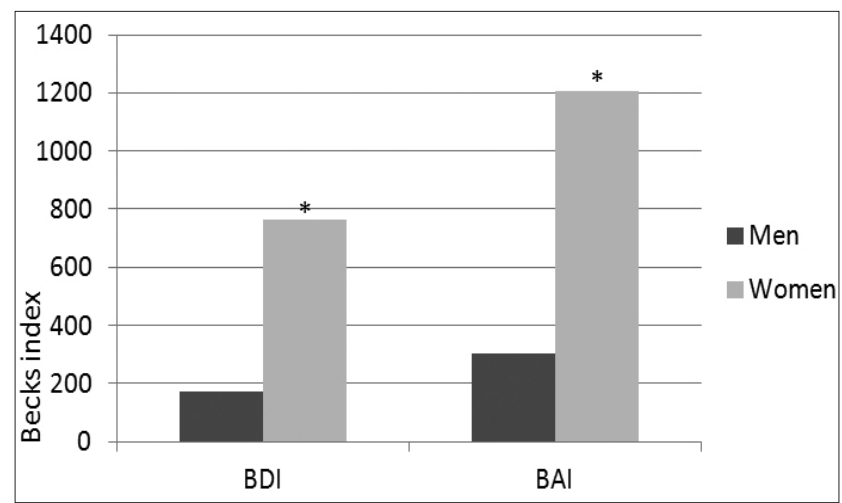

${ }^{*} p=0.003$, women versus men within the same index

Statistically significant difference between groups was found regarding BAI and BDI (Figure 3).

Figure 3. Values of the Beck Anxiety Index (BAI) and Depression (BDI) in the patient groups

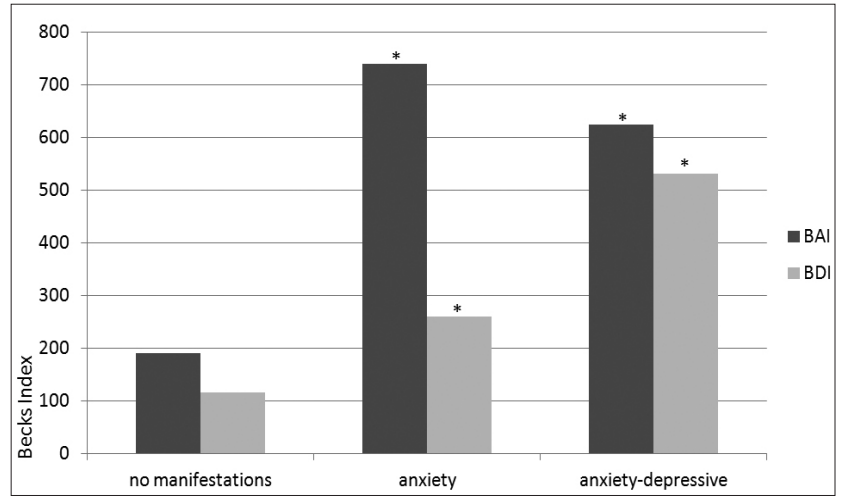

* $p<0.05$ versus the values in the group without manifestations

In terms of CSS on admission and at discharge, there is no gender difference, but it is clear that the values of these scores are reduced after treatment because they are significantly lower at disharge (Figure 3a).

Figure 3a. Values of Cervical Spine Score (CSS) before (CSSadmin) and after physical therapy (CSSdischarge) in patients of both gender

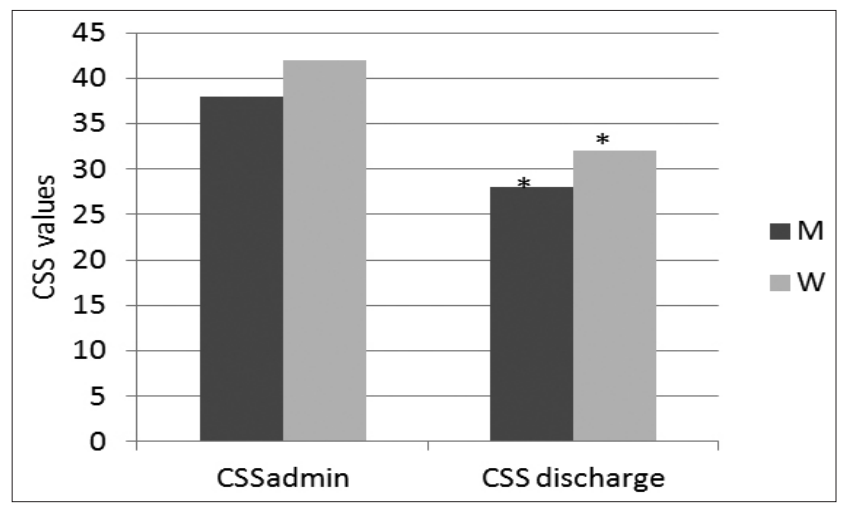

* $P<0.05$ relative to the CSSadmin value (CSSadmin)

Statistically significant difference between groups was found in CSS on admission and CSS at discharge (Figure 4). CSS values before and after physical therapy were such that the spine function in all three groups of patients was improved at discharge (Figure 4). While the CSS values of the three groups of patients did not differ on admission, CSS at discharge were significantly worse in the group with anxiety, and especially with anxietydepressive manifestations of the personality (Figure 4). 
Figure 4. Values of Cervical Spine Score (CSS) before and after physical therapy in groups of patients.

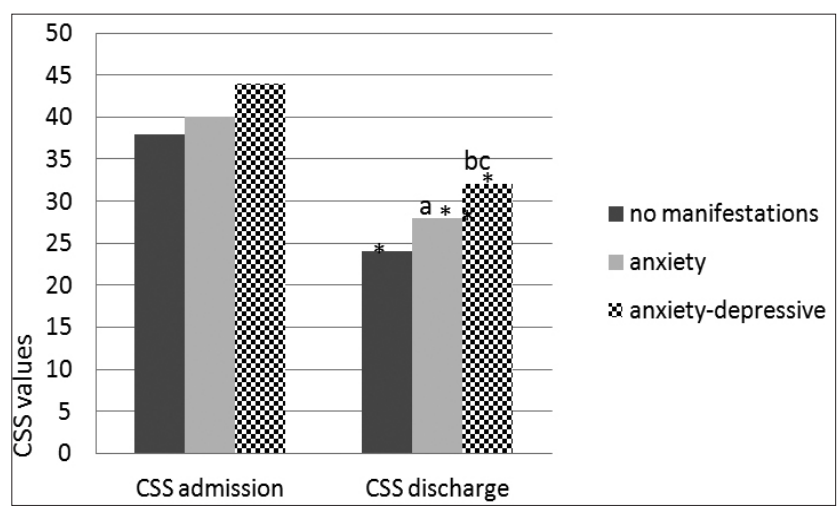

${ }^{*} p=0.05$ relative to CSS on admission. $a-p<0.05$ CSS in patients with anxiety disorder compared to the group without psychopathological manifestation of personality, $b-p<0.05$ CSSdischarge in patients with anxiety-depressive manifestation of personality in relation to a group without a psychopathological manifestation of personality, c - CSSdischarge in patients with anxiety-depressive manifestation of personality in relation to a group of patients with anxiety manifestation of personality.

Regarding the mobility of the cervical spine, a significant increase in mobility was observed in all groups at discharge compaired to admission, mostly in the group without disorders and in the group of anxiety manifestations, and the least in the group of anxietydepressive manifestations (Figure 5).

Figure 5. Mobility of the cervical spine measured by the Schober index on admission and at discharge

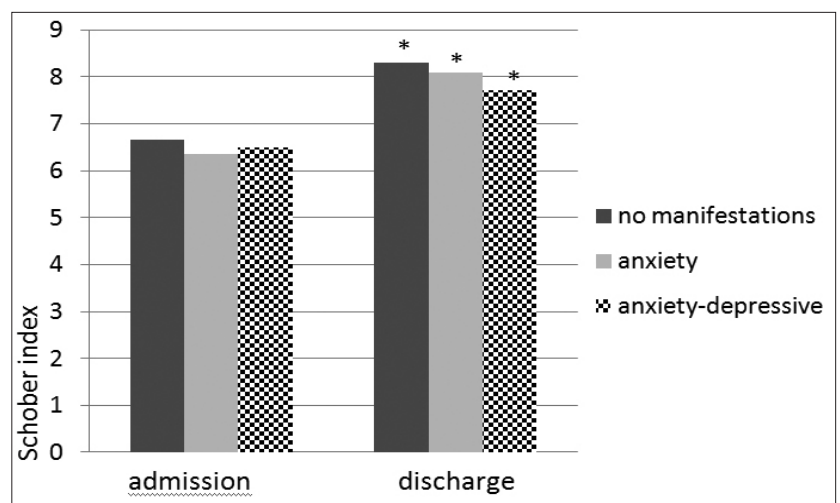

* $P=0.0001$ compared to the value of Schober's index on admission

In terms of the intensity of the pain examined by the visual analogue scale of the pain (VAS),we found a significant decrease in the value, reduction of pain for all three groupsat discharge compaired to admission (Figure $6)$.

Figure 6. Score on visual analogue scale (VAS) for admission and discharge

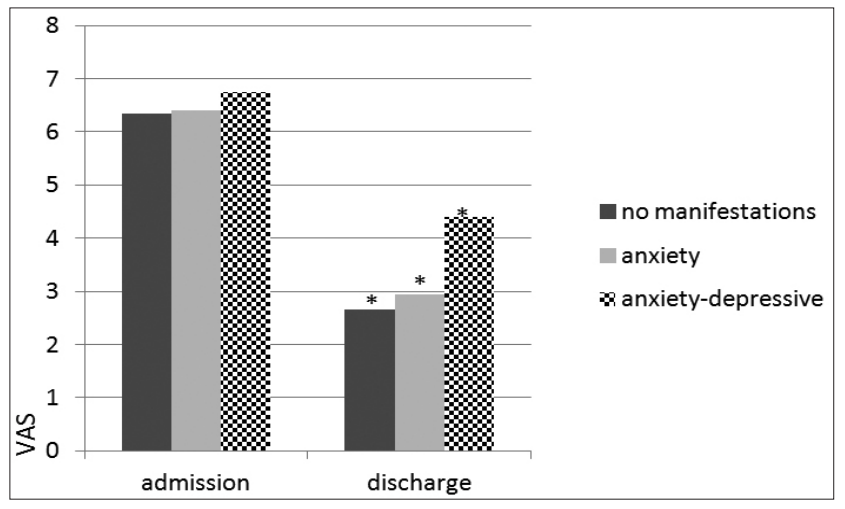

${ }^{*} p=0.0001$ in relation to the value of VAS on admission

Through comparison of the BAI values with three functional tests prior to the start of physical therapy we found a statistically significant correlation only between BAI and CSS (Table 2).

Table 2. Correlations of the Beck Anxiety Index (BAI) and the value of the functional tests on admission

\begin{tabular}{lcccc} 
Parameter & BAl & $\begin{array}{c}\text { Schober- } \\
\text { adm }\end{array}$ & CSSadm & VASadm \\
BAl & & NS & 0.001 & NS \\
Schober-pr & NS & & NS & NS \\
CSSpr & 0.001 & NS & & NS \\
VASpr & NS & NS & NS & \\
\hline
\end{tabular}

Through comparison of the BDI values with three functional tests prior to the start of physical therapy we found a statistically significant correlation only between BDI and CSS (Table 3).

Table 3. Correlations of the Beck Depression Index (BDI) and the value of the functional tests on admission

$\begin{array}{lcccc}\text { Parameter } & \text { BDI } & \begin{array}{c}\text { Schober- } \\ \text { adm }\end{array} & \text { CSSadm } & \text { VASadm } \\ \text { BDI } & \text { NS } & 0.001 & \text { NS } \\ \text { Schober-pr } & \text { NS } & & \text { NS } & \text { NS } \\ \text { CSSpr } & 0.001 & \text { NS } & & \text { NS } \\ \text { VASpr } & \text { NS } & \text { NS } & \text { NS } & \end{array}$


When the differences between the values of these parameters on admission and discharge are calculated and when they are expressed in percentage of the value on admission we got results that are shown in Table 4.

Table 4. Percentual changes in parameters $(\Delta$ Schober, $\triangle$ CSS and $\triangle$ VAS) in patients without disorders and with anxiety and anxiety-depressive disorder

\begin{tabular}{lccccc} 
Parameter & Group & N & Mean & $\begin{array}{c}\text { Std. } \\
\text { Error }\end{array}$ & $\begin{array}{c}\text { Signifi- } \\
\text { cance }\end{array}$ \\
\multirow{4}{*}{ Schober } & 1 & 32 & 29.49 & 4.59308 & $\mathrm{n} / \mathrm{a}$ \\
& 2 & 41 & 29.35 & 4.94016 & $\mathrm{NS}$ \\
$\Delta$ CSS & 3 & 27 & 20.24 & 2.73579 & $\mathrm{NS}$ \\
& 1 & 32 & 69.98 & 2.17091 & $\mathrm{n} / \mathrm{a}$ \\
& 3 & 41 & 76.01 & 1.98804 & $\mathrm{NS}$ \\
$\Delta$ VAS & 27 & 82.9 & 1.78019 & $\mathrm{p}<0,05$ \\
& 2 & 41 & 49.17 & 2.70067 & $\mathrm{NS}$ \\
& 3 & 27 & 54.32 & 4.46114 & $\mathrm{NS}$ \\
\hline
\end{tabular}

$\Delta$ Schober, $\Delta$ CSS and $\Delta$ VAS - differences in the values of the parameters of the drive and release, expressed in percentages of the receive value. $\mathrm{P}<0.05$ - significance in relation to a group of patients without psychopathology. 1 - Group of patients without psychopathology, 2 - Group of patients with anxiety manifestation of personality, 3 Group of patients with anxiety-depressive manifestation of personality.

Among these monitored parameters, only the value of $\Delta \mathrm{CSS}$ in the group of patients with anxiety-depressive personality disposition reached statistical significance in relation to the group without psychopathological manifestations of the personality, although the value of the same parameter in the group with anxiety manifestation the personality was close to the statistical significance threshold $(\mathrm{p}<0.052)$. Although the values of other parameters in patients with depressive, and especially with anxiety-depressive personality disposition tend to be worse than in patients without psychopathological symptomatology, these differences did not reach statistical significance.

Tables 5, 6 and 7 show Pearson's correlations between the depression and anxiety parameters (BDI, BAI) and values of fuctional tests expressed as a percentage change (improvement) at discharge compared to those at admission ( $\Delta$ Schober, $\Delta$ CSS, $\Delta$ VAS), and specifically for each group of patients (without symptoms, with anxiety and anxiety-depressive manifestation of personality).

In patients without anxiety and depressive manifestations of the personality, a correlation between the results of BDI and BAI was found, as well as between the values of $\Delta$ Schober and $\Delta$ CSS, and $\Delta$ VAS (Table 5).

Table 5. Correlations between depression and anxiety tests (BDI, BAI) and improvement of functional parameters on discharge, expressed as a percentage of their admission values ( $\Delta$ Schober, $\Delta$ CSS and $\triangle$ VAS) in patients without anxiety and anxiety-depressive manifestations

\begin{tabular}{lccccc} 
Parameter & BDI & BAl & $\begin{array}{c}\Delta \\
\text { Schober }\end{array}$ & $\Delta$ CSS & $\Delta$ VAS \\
BDI & & $<0.01$ & NS & NS & NS \\
BAl & $<0.01$ & & NS & NS & NS \\
$\Delta$ Schober & NS & NS & & NS & $<0.01$ \\
$\Delta$ CSS & NS & NS & NS & & $<0.05$ \\
$\Delta$ VAS & NS & NS & $<0.01$ & $<0.05$ & \\
\hline
\end{tabular}

$N S$ - not significant

In patients with anxiety symptoms, the correlation was found only between BDI and BAI values (Table 6).

Table 6. Correlations between depression and anxiety tests (BDI, BAI) and improvement of functional parameters on discharge, expressed as a percentage of their admission values $\Delta$ Schober, $\Delta$ CSS and $\triangle$ VAS in patients with anxiety manifestation of personality

\begin{tabular}{lccccc} 
Parameter & BDI & BAl & $\begin{array}{c}\Delta \\
\text { Schober }\end{array}$ & $\Delta$ CSS & DVAS \\
BDI & & $<0.01$ & NS & NS & NS \\
BAl & $<0.01$ & & NS & NS & NS \\
$\Delta$ Schober & NS & NS & & NS & NS \\
$\Delta$ CSS & NS & NS & NS & & NS \\
$\Delta$ VAS & NS & NS & NS & NS & \\
\hline
\end{tabular}

$N S$ - not significant

In patients with anxiety-depressive symptoms, correlations between BDI i BAI, and also between $\Delta$ Schober, $\Delta$ CSS and $\Delta$ VAS (Table 7 ) were found. 
Table 7. Correlations between depression and anxiety tests (BDI, BAI) and improvement of functional parameters on discharge, expressed as a percentage of their admission values $\Delta$ Schober, $\Delta$ CSS and $\triangle$ VAS) in patients with anxietydepressive symptoms

\begin{tabular}{|c|c|c|c|c|c|}
\hline Parameter & $\mathrm{BDI}$ & $\mathrm{BAl}$ & $\begin{array}{c}\Delta \\
\text { Schober }\end{array}$ & $\triangle \mathrm{CSS}$ & $\triangle \mathrm{VAS}$ \\
\hline BDI & & $<0.01$ & NS & NS & NS \\
\hline BAI & $<0.01$ & & NS & NS & NS \\
\hline$\Delta$ Schober & NS & NS & & $<0.01$ & $<0.05$ \\
\hline$\Delta \mathrm{CSS}$ & NS & NS & $<0.01$ & & $<0.01$ \\
\hline$\triangle V A S$ & NS & NS & $<0.05$ & $<0.01$ & \\
\hline
\end{tabular}

NS - not significant

\section{Discussion}

The results of this study showed that $77 \%$ of the patients involved in the study had some form of psychopathological manifestation of the personality. The presence and intensity of these disorders did not have a negative effect on the functional recovery of patients after a physical rehabilitation treatment. We found a statistical improvement in terms of increased mobility of cervical spine and reduced pain, in all three groups at discharge comparing to admission ( $\mathrm{p}<0.0001)$.

Physical therapy has led to a statistically significant improvement in the cervical spine function (CSS), the smallest improvement was in group 3 (difference between groups 1 and 3, 2 and 3 at discharge $\mathrm{p}<0.05$ ). The presence of anxiety and depressive manifestations of the personality did not significantly affect the outcome of the physical rehabilitation treatment in terms of reduced pain and increased mobility of the spine in all three groups of patients, but had an effect in terms of lesser functional recovery in the group of anxiety depressive patients. In order to reduce the discomfort of these patients, different types of therapy are used, primarily therapeutic exercises that can relieve symptoms, as in reduce pain and improve the function of the cervical spine. ${ }^{20,21}$ Engaging patients in relaxation groups under the supervision of psychologists can mitigate anxiety and depressive symptomatology and contribute to faster recovery of patients.

The association of anxiety and depression with chronic neck pain was demonstrated by a group of experts through a national cross-section study conducted in 19 countries (52,095 participants). It was concluded that the earlier onset of mental disorders was a strong predictor of pain in the neck compared to the later onset. ${ }^{10}$
The correlation of various mental disorders with 10 different pain syndromes has been demonstrated by a group of experts with a cross section study involving 17 countries (47,609 participants). Accent was placed on the primary prevention of chronic pain conditions as part of the treatment of all mental disorders at the primary and secondary levels. ${ }^{11}$

A group of Turkish authors has shown that anxiety disorders and mood swings are often found in patients with lumbar and cervical herniation of the intervertebral disc or without herniation. Anxiety disorders and mood swings were associated with pain, but they also found an association with neurological deficits. ${ }^{12}$

On the other hand, a group of Dutch authors followed 1121 patients with chronic pain syndrome and concluded that pain, rather than chronic illness, lead to the occurrence of anxiety disorders and worsening of depression..$^{13,14}$

Wasan et $a .^{15}$ have shown that psychiatric disorders and imparing of the quality of life are more common in men with chronic back pain on the left side then in women. This was explained by the fact that in men the right hemisphere of the brain is predominantly involved in processing the pain.

There are several limitations of our research: uneven representation of female and male sex (74/26) as well as the fact that patients are recruited from one health institution.

In the available literature, no data on the influence of psychopathological manifestations on the outcome of physiorehabilitation treatment were found, which contributes to the originality of the results of our study.

This study has shown that physical therapy has a positive effect on pain reduction, increase of the range of motion in the cervical spine, and the improvement of the functional status of the cervical spine in patients with cervical pain syndrome. The presence of anxiety and depressive manifestations of the personality has slowed down the functional recovery for a group of patients with anxiety and depressive manifestations inasmuch as the intensity of these disorders was higher, but did not have an effect on the reduction of pain and mobility of the cervical spine. Therefore, it is important to emphasize the importance of early assessment of the psychological status of patients with cervical pain syndrome in order to achieve faster and better results through comprehensive physical treatment and relaxation techniques. 


\section{Conclusion}

The presence of anxiety and depressive manifestations of personality did not have a negative impact on the functional recovery of patients. Physical therapy has led to reduction of pain, increased mobility and better functional status of cervical spine for patients with cervical spine syndrome.

\section{References}

1. Jevtić RM. Fizikalna medicina i rehabilitacija, Kragujevac: Medicinski fakultet, 1999.

2. Jandrić S.Osnovi fizikalne medicine i rehabilitacije.Banja Luka:Grafomark,2005, p. 111-6.

3. Markotić V, Zubac D, MIljko M, Šimunić G, Zalihić A, Bogdan G, et al. Level of education as a risk factor for extensive prevalence of cervical intervertebral disc degenerative changes and chronic neck pain. Cent Eur J Public Health 2017;25:245-250.

4. Pereira FG, Franca MH, Paiva MCA, Andrade LH, Viana MC. Prevalece and clinical profile of chronic pain and its assotiation with mental disorders. Rev Saude Publica 2017;17;51:96.

5. Fejer R, Kyvik KO, Hartvigsen J. The prevalence of neck pain in the world population: a systematic critical review of the literature. Eur Spine J 2006;15:834-848.

6. Dvorak J. Epidemiology, phisical examination, and neurodiagnostics. Spine 1998 Dec 15;23(24):266-73.

7. Rezai M, Cote P, Cassidy JD, Carroll L. The association between prevalent neck pain and health-related quality of life: a cross-sectional analysis. Eur Spine J2009;18(3):37181.

8. Jull GA, Falla D, Vicenzino B, Hodges PW. The effect of therapeutic exercise on activation of the deep cervical flexor muscles in people with chronic neck pain. Manual therapy 2009;14:696-701.

9. Philadelphia panel evidence. Based clinical pratice guidelines as selected rehabilitation interventions for neck pain. Phys Ther 2001;81:1701-17.

10. Viana MC, Lin CCW, Garcia Pereira F, AguilarGaciola S, Alonso J, Bruffaertes R et .Previous mental disorders and subsequement onset of chronicback or neck pain, findings from 19 countries. J Pain 2018;19:99-110.

11. Scott KM, Lim C, Al-Hamzawi, Alonso J, Bruffaertes R, Caldas-de-Almeida JM et al. Assotiation of mental disorders with subsequent chronic physical conditions:World mental health surveys from 17 countries. JAMA Physiatry 2016:73:150-8.

12. Kayhan F, Albayrak Gezer I, Kayhan A, Kitis S, Goten M. Mood and anxiety disorders in patients with chronic low back and neck pain caused disc herniation. Int J Psychiatry Clin.Pract 2016;20(1):19-23.

13. Gerrits MM, van Oppen P, Leone SS, van Marwijk HW, van der Horst HE, Penninx BW. Pain not chronic disease, is associated with the recurrence of depressive and anxiety disorders. BMC Psychiatry 2014 25;14:187

14. Gerrits MM, van Oppen P, van Marwijk HW, van der Horst HE, Penninx BW. Pain and the onset of depressive and anxiety disorders Pain 2014;155(1):53-9

15. Wasan AD, Anderson NK, Giddon DB. Differences in pain , psychological symptoms and gender distribution among patients with left-vs-right sided chronic spinal pain. Pain Med 2010;11(9):1373-80.

16. Langenfeld A, Bastianen C, Brunner F, Swanenburg J. Validation of the Orebro musculoskeletal pain screening questionnaire in patients with chronic neck pain. BMC Res Notes 2018;11:161.

17. Wang J, Wu X, Lai W, Long E, Zhang X, Zhy Y, et al. Prevalence of depression and depressive symptoms omong outpatients :a systematic review and meta analysis. BMJ Open 2017; 23;7:e017173.

18. Verhaak PFM, Kerssens JJ, Dekker J, Sorbi MJ, Bensing JM. Prevalence of chronic benign pain disorder among adults: a review of the literature. Pain 1998;77(3):231-239

19. Vos T, Flaxman AD, Naghavi M, Lozano R, Michaud C, Ezzati M, et al. Years lived with disability (YLDs) for 1160 sequelae of 289 diseases and injuries 1990-2010: a systematic analysis for the Global Burden of Disease Study 2010 Lancet. 2012;380(9859):2163-2196

20. Harstall C, Ospina M. How prevalent is chronic pain? [cited 2017 Mar 24];Pain Clin Updat. 2003;11(2):1-4

21. LeResche L. Gender considerations in the epidemiology of chronic pain. In: Crombie LK, editor, editor. Epidemiology of pain. Seattle: IASP Press; 1999. pp. 43-52.

22. Bras M, Dordevic V, Gregurek R, Bulajic M. Neurobiological and clinical relationship between psychiatric disorders and chronic pain. [cited 2017 Mar 24];PsychiatrDanub. 2010;22(2):221-226.

23. Gureje O, Von Korff M, Kola L, Demyttenaere K, He Y, Posada-Villa J, et al. The relation between multiple pains and mental disorders: results from the World Mental Health Surveys Pain 2008;135(1-2):82-91.

24. Dersh J, Gatchel R, Polatin P, Mayer T. Prevalence of psychiatric disorders in patients with chronic work-related musculoskeletal pain disability. J Occup Environ Med 2002;44(5):459-68.

25. Physical activity and exercise for chronic pain in adults: an overview of Cochrane Reviews.Cochrane database Syst Rev2017;24;4.

26. Harris A, Moe TF, Eriksen HR, Tangen T, Lie SA, Tveito TH et al. Brief intervention, physical exercise and cognitive behavioural group therapy for patients with chronic low back pain. Eur J Pain2017;21:1397-1407.

27. Kahan M, Wilson L, Mailis-Gagnon A, Srivastava A, National Opioid Use Guideline Group Canadian guideline for safe and effective use of opioids for chronic noncancer pain: clinical summary for family physicians. Part 2: special populations. Can Fam Physician 2011;57:1269-76. 
28. Chou R, Turner JA, Devine EB. The effectiveness and risks of long-term opioid therapy for chronic pain: a systematic review for a National Institutes of Health Pathways to Prevention Workshop. Ann Intern Med 2015;162:276-86.

29. Kuo HW, Tsai SS, Tiao MM, Liu YC, Lee IM, Yang CY. Analgesic use and the risk for progression of chronic kidney disease. Pharmacoepidemiol Drug Saf. 2010;19:745-51.

30. Beck AT, Ward C, Mendelson M. Beck Depression Inventory (BDI). Arch Gen Psychiatry 1961;4(6):561-71.

31. RichterP,Werner, J A Heerlein, A Kraus, H Sauer. On the validity of the Beck Depression Inventory. A review. Psychopathology 1998;31(3):160-8.

32. Leyfer, OT, Ruberg JL, Woodruff-Borden J. Examination of the utility of the Beck Anxiety Inventory and its factors as a screener for anxiety disorders. J Anxiety Disord 2006;20(4):444-58.

33. Boyd JH, Weissman MM, Thompson WD, Myers JK. Screening for depression in a community sample. Understanding the discrepancies between depression symptom and diagnostic scales. Arch Gen Psychiatry 1982;39(10):1195-200.

34. Korff M, Le Resche L, Dworkin SF. First onset of common pain symptoms: a prospective study of depression as a risk factor. Pain 1993;55(2):251-8.

35. Luo X, Edwards CL, Richardson W, Hey L. Relationships of clinical, psychologic, and individual factors with the functional status of neck pain patients. Value Health 2004;7(1):61-9.

\section{Uticaj anksioznih i depresivnih ispoljavanja ličnosti na funkcionalni oporavak pacijenata sa cervikalnim bolnim sindromom}

\section{SAŽETAK}

Uvod: Cervikalni sindrom predstavlja skup simptoma koji se manifestuju bolom u vratnom segmentu i rameno-lopatičnoj regiji ali i osjećajem zatezanja i napetosti, te ograničenih pokreta vratnog segmenta kičme. Zbog dugotrajnosti simptoma često kod ovih pacijenata možemo naći psihopatološka ispoljavanja u vidu anksioznosti i depresije.

Cilj rada: Cilj je bio detektovati na početku rehabilitacionog tretmana prisustvo anksioznih i depresivnih ispoljavanja ličnosti kod pacijenata sa cervikalnim sindromom, ispitati koliko prisustvo anksiozne i depresivne simptomatologije utiče na funkcionalni oporavak pacijenata nakon provedenog fizikorehabilitacionog tretmana.

Pacijenti i metode: Istraživanje je provedeno kao prospektivna studija u koju je uključeno 100 pacijenata. Kriterijumi za uključenje su bili dijagnoza cervikalnog sindroma istarost pacijenata od 20-60 godina. Kriterijumi za neuključenje su bill dijagnoza cervikalne radikulopatije, vertebrobazilarnog sindroma, od strane psihijatra potvrđena anksioznost i depresija kao i uzimanje psihotropnih supstanci. Na prijemu je svaki pacijent popunjavao Beckov upitnik za anksioznost i depresiju (BAl i BDI) i prema tome su pacijenti podijeljeni u 3 grupe.

Rezultati: Od ukupno 100 ispitanika 74\% su bile žene i 26\% muškarci.Kod 77\% ispitanika su nađena psihopatološka ispoljavanja ličnosti.Utvrđena je statistički značajna povezanost pola i pripadnosti nekoj od grupa $(p=0,003)$.Žene su u daleko većem procentu imale anksiozna i anksiozno-depresivna ispoljavanja ličnosti nego muškarci. Nađena je statistički značajna razlika između polova kada je riječ o BDI I BAI. Svi praćeni parametri (VAS, Schober, CSS) nakon provedenog fizikorehabilitacionog tretmana su u svim grupama poboljšani na otpustu ( $p=0,0001)$. Nađena je pozitivna korelacija BAI i BDI sa CSS-om na prijemu i otpustu $(p=0,05)$ u grupi anksiozno depresivnih pacijenata.

Zaključak: Prisustvo anksioznih i depresivnih ispoljavanja ličnosti nije imalo negativan uticaj na funkcionalni oporavak pacijenata. Fizikalna terapija kod pacijenata sa cervikalnim sindromom je dovela do smanjenja bola, povećanja pokretljivosti i boljeg funkcionalnog statusa vratne kičme.

Ključne riječi: cervikalni sindrom, funkcionalni oporavak, depresija, anksioznost 